\title{
Application of High Pressures in the Postharvest Conservation of Broccoli
}

\author{
Emmanuel M. Pereira ${ }^{1,2,3}{ }^{\mathbb{D}}$, Anderson S. Formiga ${ }^{3}{ }^{(0}$, José S. Pinzetta Junior ${ }^{3}$, Isabela N. F. Cordeiro ${ }^{3,4}$, \\ Karollayne T. E. F. Oliveira ${ }^{3}$, Mônica Tejo Cavalcanti ${ }^{1,5}$ and Ben-Hur Mattiuz ${ }^{6, *}$
}

1 National Semiarid Institute, Campina Grande 10067-000, Brazil; emmanuel.pereira@insa.gov.br (E.M.P.); monica.tejo@insa.gov.br (M.T.C.)

2 Center for Human, Social and Agrarian Sciences, Department of Agriculture, Federal University of Paraíba, Bananeiras 58220-000, Brazil

3 School of Agricultural and Veterinarian Sciences, Department of Technology, São Paulo State University, Jaboticabal 14884-900, Brazil; andersondossantos1991@hotmail.com (A.S.F.); josepinzettajunior@gmail.com (J.S.P.J.); isabela.cordeiro@ifma.edu.br (I.N.F.C.); karolltomazx@gmail.com (K.T.E.F.O.)

4 Federal Institute of Maranhão, Campus Codó, Codó 65400-000, Brazil

5 Center for Agro-Food Science and Technology, Federal University of Campina Grande, R. Jairo Vieira Feitosa, 1770, Pombal 58840-000, Brazil

6 Institute of Biosciences, Department of General and Applied Biology, São Paulo State University, Av. 24A 1515, Rio Claro 13506-900, Brazil

* Correspondence: b.mattiuz@unesp.br; Tel.: +55-193-526-4179

Citation: Pereira, E.M.; Formiga, A.S.; Pinzetta Junior, J.S.; Cordeiro, I.N.F.; Oliveira, K.T.E.F.; Cavalcanti M.T.; Mattiuz, B.-H. Application of High Pressures in the Postharvest Conservation of Broccoli. Agronomy 2021, 11, 2157. https://doi.org/ 10.3390 /agronomy11112157

Academic Editor: Ewelina Hallmann

Received: 14 September 2021

Accepted: 25 October 2021

Published: 27 October 202

Publisher's Note: MDPI stays neutral with regard to jurisdictional claims in published maps and institutional affiliations.

Copyright: (c) 2021 by the authors. Licensee MDPI, Basel, Switzerland. This article is an open access article distributed under the terms and conditions of the Creative Commons Attribution (CC BY) license (https:/ / creativecommons.org/licenses/by/ $4.0 /)$.
Abstract: Broccoli is a vegetable of high nutritional value, rich in bioactive compounds, but has a fast degradation after harvest. This work assesses the effect of hyperbaric pressure, at room temperature, on postharvest conservation of broccoli. The broccoli samples were subjected to the five hyperbaric pressures (100 control, 200, 400, 600, and $800 \mathrm{kPa}$ ) during three different times (1, 2, and 3 days), at $22{ }^{\circ} \mathrm{C}$ and $95 \% \mathrm{RH}$. The pressures of 400,600 , and $800 \mathrm{kPa}$ provided the best conservation of broccoli quality. Respiratory rate, ethylene production, soluble solids content, and lipid peroxidation decreased at the highest-pressure treatments. Moreover, the highest pressures maintained fresh mass, green color, ascorbic acid content, and receptacle firmness. The hyperbaric treatments of 600 and $800 \mathrm{kPa}$ increased catalase enzymatic activity and reduced peroxidase activity as a result of the reduction of oxidative stress, delaying the senescence of broccoli.

Keywords: Brassica oleracea var. Itálica; food quality; hyperbaric atmosphere; inflorescence

\section{Introduction}

Vegetable production increases by around 5 million tonnes per year [1]. The population's search for a healthy life may be the leading cause of this growth. Among these vegetables, broccoli has stood out because of its high nutritional value and nutraceutical properties, such as high levels of beta-carotene, vitamin C, selenium, fiber, lutein, zeaxanthin, vitamin K, folic acid, and minerals such as calcium, potassium, phosphorus [2-4].

Broccoli has high perishability, with a shelf life of only two days at room temperature [5]. This rapid senescence is due to the high production of ethylene and respiratory rates, requiring refrigeration to prolong the shelf life of this vegetable, making the production process more expensive.

Recent studies have shown the benefits of using hyperbaric pressures to retard the physiological mechanisms of maturation and senescence in vegetables. Hyperbaric pressure delayed maturation in tomatoes, as evidenced by the reduction in respiratory rate and maintenance of color and firmness [6-8]. Tomatoes submitted to pressures of 600 and $800 \mathrm{kPa}$ at room temperature showed biochemical changes, such as the increased catalase activity and decrease in peroxidase [9]. 
The application of pressure treatment at room temperature can induce positive effects on the physiological activity of the vegetables in a similar way to refrigerated storage $[7,8,10,11]$. Since pressurizing uses only $3 \%$ of the energy required in the refrigeration, this technique allows for energy savings. The economy that occurs due to the pressurizing does not have to be instantaneous, and it takes little energy to maintain the pressure throughout the storage [8].

In this sense, this work aims to evaluate the effect of the application of hyperbaric pressures at room temperature on the postharvest quality of broccoli 'Legacy'.

\section{Materials and Methods}

\subsection{Vegetable Material}

The broccoli 'Legacy' were obtained in commercial crops of Taiúva county $\left(21^{\circ} 7^{\prime} 24.87^{\prime \prime}\right.$ S, $48^{\circ} 27^{\prime} 8.83^{\prime \prime}$ W, 634 m altitude), São Paulo, Brazil.

The inflorescences were harvested at commercial maturation stage (about 80 days after sowing, in the winter of 2018) and transported to the laboratory in $30 \mathrm{~min}$. The sampling was homogenized by choosing inflorescences with similar shape and color, mean weight of $630 \pm 60 \mathrm{~g}$, and absence of diseases. All inflorescences were sanitized in a solution of Sodium Dichloro-s-triazinetrione Dihydrate (Sumaveg ${ }^{\circledR}$, Diversey, Socorro, SP, Brazil) at $200 \mathrm{mg} \mathrm{L}^{-1}$ for five minutes and allowed to dry in a cold room at $22{ }^{\circ} \mathrm{C}$ for $2-4 \mathrm{~h}$ at the place where the treatments were applied.

\subsection{Hyperbaric System}

The experiments were performed in a hyperbaric system as described by InestrozaLizardo [9].

The system comprised five steel chambers with $10.75 \mathrm{~L}$ each, interconnected to a closed circuit through which a constant flow of compressed air circulated, keeping constant the partial pressures of oxygen $(21 \mathrm{kPa})$ and nitrogen $(78 \mathrm{kPa})$. The previous passage of air adsorbed the $\mathrm{CO}_{2}$ into a chamber containing calcium oxide.

The treatment chambers are equipped with a pressure regulator at the input and needle valve at the output of each vessel to regulate air pressure and airflow, respectively, in addition to a safety valve. The system was connected to a $250 \mathrm{~L}$ air compressor (Schulz, model MSV 20 MAX, Joinville, Santa Catarina, Brazil) that supplied compressed air. The air flow was measured using a flowmeter in a range of $5-2000 \mathrm{~mL} \mathrm{~min}^{-1}$ (Bronkhorst ${ }^{\mathrm{TM}}$, Ruurlo, The Netherlands). The $\mathrm{CO}_{2}$ concentration was measured in an infrared gas analyzer (Guardian ${ }^{\circledR P l u s, ~ E d i n b u r g h ~ S e n s o r ' s, ~ L i v i n g s t o n, ~ U K) . ~ T h e ~ f l o w m e t e r ~ a n d ~} \mathrm{CO}_{2}$ analyzer were connected to the acquisition and control card (PersonnelDAQ 3000, Cleveland, $\mathrm{OH}, \mathrm{USA}$ ) and a computer. Pressure, airflow rate, and $\mathrm{CO}_{2}$ level were recorded using DasyLab®software (Measurement Computing Corporation, Norton, MA, USA).

\subsection{Experimental Procedure}

Each replicate of the experiment comprised twelve inflorescences, two of which were used to characterize the initial quality (day 0) (Table 1) and ten were distributed in the five chambers of the system (two inflorescences per chamber). Then, the chambers were closed and pressurized at 100 (control), 200, 400, 600, and $800 \mathrm{kPa}$ for periods of 1, 2, and 3 days. Data loggers (HOBO Prov2 U-23-001, Onset Corporation, Bourne, MA, USA) monitored temperature $\left(22 \pm 1^{\circ} \mathrm{C}\right)$ and relative air humidity $(95 \pm 2.0 \%)$ within the chambers every $30 \mathrm{~min}$. At the end of each treatment period, the chambers were automatically depressurized for two hours. The inflorescences were removed from the chambers and evaluated. 
Table 1. Initial characterization of broccoli 'Legacy'.

\begin{tabular}{|c|c|}
\hline Variables & Values \\
\hline Mass (g) & $630 \pm 60$ \\
\hline Epidermis color index & $1.04 \pm 0.10$ \\
\hline Receptacle firmness $(\mathrm{N})$ & $13.3 \pm 1.02$ \\
\hline Ethylene production $\left(\mathrm{mL} \mathrm{C}_{2} \mathrm{H}_{4} \mathrm{~kg}^{-1} \mathrm{~h}^{-1}\right)$ & $5.2 \pm 1.2$ \\
\hline Soluble solids $(\%)$ & $6.17 \pm 0.05$ \\
\hline Titratable acidity $\left(\mathrm{g} \mathrm{kg}^{-1}\right)$ & $0.14 \pm 0.07$ \\
\hline Ascorbic acid (mg kg $\left.{ }^{-1}\right)$ & $99.6 \pm 2.40$ \\
\hline Antioxidant activity $\left(\mathrm{mmol} \mathrm{kg}^{-1}\right)$ & $0.23 \pm 0.20$ \\
\hline Lipid peroxidation (mmol kg $\left.{ }^{-1}\right)$ & $19.22 \pm 1.6$ \\
\hline Catalese activity $\left(\mathrm{U} \mathrm{kg}^{-1} \mathrm{pt}\right)$ & $1.12 \times 10^{-10} \pm 0.1$ \\
\hline Peroxidase activity ( $\left.\mathrm{U} \mathrm{kg}^{-1} \mathrm{pt}\right)$ & $0.03 \pm 0.01$ \\
\hline
\end{tabular}

Values represent the mean \pm standard deviation.

\subsection{Physical, Metabolic, and Chemical Analyses}

The weight loss was calculated by the difference between initial and final inflorescence weight divided by the initial weight. The samples were weighed on an electronic scale with a measuring range of 50-6000 g \pm 2 g (BP6, Filizola, São Paulo, SP, Brazil). We expressed the result as a $\mathrm{g} \mathrm{kg}^{-1}$.

The color index (CI) included the luminosity parameters $\mathrm{L}^{*}, \mathrm{a}^{*}$, and $\mathrm{b}^{*}$ (Minolta CR400 colorimeter, Konica Minolta, New Jersey, NJ, USA) [12]. Readings were taken in five points on each inflorescence, and the CI was calculated using Equation (1):

$$
C I=\left(100 \times a^{*}\right) /\left(L^{*} \times b^{*}\right)
$$

The firmness was measured using a digital penetrometer with $8 \mathrm{~mm}$ tip (5-200 N \pm 1 N, Impac, IP-90DI, São Paulo, SP, Brazil) and evaluated at the base of the receptacle (receptacle firmness). The results were expressed in Newton $(\mathrm{N})$.

The respiratory rate (RR), $\mathrm{CO}_{2}$ concentration, was measured using an infrared gas analyzer (Guardian ${ }^{\circledR} P$ lus, Edinburgh Sensors, Livingston, UK) connected to a data acquisition and control card (Personnel DAQ 3000, Cleveland, $\mathrm{OH}, \mathrm{USA}$ ) and a laptop computer. $\mathrm{CO}_{2}$ levels were recorded using DasyLab®software (Measurement Computing Corporation, Norton, MA, USA) throughout the experiment and calculated automatically in real time during the whole trial, according to Equation (2) [13]:

$$
\mathrm{RR}=\left(\Delta \mathrm{CO}_{2} \times \mathrm{Q}\right) / \mathrm{W}
$$

where $\Delta \mathrm{CO}_{2}$ is the difference between the concentration of $\mathrm{CO}_{2}$ at the inlet and outlet of chambers, $\mathrm{Q}$ is the air flow rate, and $\mathrm{W}$ is the mass of broccoli. The results were expressed in $\mathrm{mg} \mathrm{CO}_{2} \mathrm{~kg}^{-1} \mathrm{~h}^{-1}$.

The inflorescences were stored in $5 \mathrm{~L}$ sealed containers to estimate ethylene production. After one hour, $200 \mu \mathrm{L}$ of the gas inside containers (headspace) was collected by a silicone septum with the aid of a gas chromatography syringe (SGE, Analytical Science, Ringwood, VIC, Australia). The samples were injected in a gas chromatograph (Trace GC Ultra, Thermo Scientific, Whaltham, MA, USA) equipped with a flame ionization detector (FID), and a Porapack $\mathrm{N}$ capillary column $\left(2 \mathrm{~m}\right.$ in length) and set at $80^{\circ} \mathrm{C}$, with hydrogen as carrier gas $\left(35 \mathrm{~mL} \mathrm{~min}{ }^{-1}\right)$. The operating temperatures were $110^{\circ} \mathrm{C}$ in the column, $250{ }^{\circ} \mathrm{C}$ in the detector, and $200^{\circ} \mathrm{C}$ in the injector. Ethylene production was measured after removal of inflorescence from the chambers and was expressed in $\mathrm{\mu g} \mathrm{kg}^{-1} \mathrm{~s}^{-1}$.

Soluble solids (SS), titratable acidity (TA), and ascorbic acid (AA) were determined according to AOC methodology [14]. The results were expressed as the percentage of SS, percentage of citric acid, and $\mathrm{mg}$ of ascorbic acid $\mathrm{mg} \mathrm{kg}^{-1}$.

Peroxidation of lipids was measured according to Heath and Packer [15]. Samples were frozen in liquid $\mathrm{N}_{2}$, macerated, combined with $4 \mathrm{~mL}$ of TCA buffer $(1 \% w / v)$, homog- 
enized, and centrifuged for $10 \mathrm{~min}$ at $10,000 \times \mathrm{g}$ at $4{ }^{\circ} \mathrm{C}$ (Biofuge Stratos model, Heraeus, Hanau, Germany). A $1 \mathrm{~mL}$ aliquot was pipetted from the supernatant and transferred to a test tube, adding $3 \mathrm{~mL}$ of thiobarbituric acid at $0.5 \%(w / v)$, TCA at $20 \%(w / v)$, and incubating in a water bath at $95{ }^{\circ} \mathrm{C}$ for $60 \mathrm{~min}$. Subsequently, the tubes were held for $10 \mathrm{~min}$ in an ice bath to interrupt the reaction. The samples were then centrifuged again for $10 \mathrm{~min}$ at $10,000 \times \mathrm{g}$. The absorbance of the supernatant was measured using a UV VIS spectrophotometer (Femto 700 plus, São Paulo-SP, Brazil) at $535 \mathrm{~nm}$ and $600 \mathrm{~nm}$. We expressed the results as the malondialdehyde content (MDA) per $\mathrm{mmol} \mathrm{kg}^{-1}$.

The total antioxidant activity was estimated by the DPPH method according to BrandWilliams et al. [16]. The results were expressed in $\mathrm{mmol} \mathrm{kg}^{-1}$.

Catalase activity (CAT) (EC 1.11.1.6) was determined by the method of Kar and Mishra [17] with adaptations. We obtained the reaction combining $150 \mu \mathrm{L}$ of sample in a potassium phosphate buffer + EDTA + DTT + PVPP at $100 \mathrm{mmol} \mathrm{L}^{-1}(\mathrm{pH} 7.5)$. A total of $1950 \mu \mathrm{L}$ of potassium phosphate buffer at $100 \mathrm{mmol} \mathrm{L}^{-1}(\mathrm{pH}$ 7.5) was used as the determination buffer, $150 \mu \mathrm{L}$ of potassium phosphate buffer + EDTA + DTT + PVPP at $100 \mathrm{mmol} \mathrm{L}^{-1}$ (pH 7.5) as the extraction buffer, and $750 \mu \mathrm{l}$ of hydrogen peroxide solution at $50 \mathrm{mM}$ as the enzymatic substrate. The readings were performed in a UV VIS spectrophotometer (Femto, São Paulo, SP, Brazil) at $240 \mathrm{~nm}$ absorbance. We expressed the specific activity of CAT as $\mathrm{U} \mathrm{kg}^{-1}$ protein.

The activity of peroxidases (POD) (EC 1.11.1.7) was measured according to Lima et al. [18]. The reaction system comprised $1 \mathrm{~mL}$ of enzyme extract with $0.5 \mathrm{~mL}$ of $30 \%$ hydrogen peroxide in potassium phosphate buffer at $0.2 \mathrm{M}(\mathrm{pH} 6.7)$ and $0.5 \mathrm{~mL}$ of phenol and aminoantipyrine solution. The solution was immersed in a water bath at $30^{\circ} \mathrm{C}$ for $5 \mathrm{~min}$. Absolute ethyl alcohol $(2 \mathrm{~mL})$ was added to stop the reaction, and we assessed the absorbance in a UV VIS spectrophotometer at $505 \mathrm{~nm}$. We express the specific activity of POD as $\mathrm{U} \mathrm{kg}^{-1}$ protein.

For the calculation of the specific activity of CAT and POD, the total soluble protein content was measured using the Bradford method [19].

\subsection{Statistical Analysis}

We applied a randomized block design in a factorial scheme $(5$ pressures $\times 3$ exposure times). The data were submitted to analysis of variance (ANOVA) and Tukey tests, with $99 \%$ probability $(p<0.01)$, using AgroEstat software version 2014 [20]. When significant differences were found, we performed regression analyses.

\section{Results}

\subsection{Physicochemical Analyzes}

Weight Loss, Firmness, Color Index (CI), Soluble Solids (SS), Titratable Acidity (TA), Ascorbic Acid Content (AA)

The alteration in atmospheric pressure around the vegetable reduced the weight loss (WL) of broccoli 'Legacy' effectively. The higher the pressure, the lower the weight loss at all exposure times (1,2, and 3 days) (Figure 1A). The inflorescences subjected to $100 \mathrm{kPa}$ had the highest $\mathrm{WL}$, and the longer the exposure time, the larger the WL. After three days of treatment, broccoli at $100 \mathrm{kPa}$ lost $3 \%$ mass, while those under $800 \mathrm{kPa}$ lost only $1.2 \%$.

The increase in pressure promoted the maintenance of firmness (Figure 1B). The pressure of $800 \mathrm{kPa}$ for one day maintained the firmness of the broccoli in $12.2 \mathrm{~N}$, very close to the initial value of $13.3 \mathrm{~N}$ (Table 1 ) and higher than the control $(9.5 \mathrm{~N})$. Control broccoli had an average reduction of $11.4 \%$ in firmness compared to the initial values, but firmness values increased over the three days of storage. The high mass loss suffered by the broccoli that remained for three days in the chambers may have increased elasticity and resistance of tissues against the tip of the penetrometer.

In general, the color index $(\mathrm{CI})$ increased with time of exposure to pressure, turning the broccoli yellowish (Figure 1C), which may be attributed to at least three factors: (1) the 
degradation of chlorophylls by the enzyme chlorophyllase; (2) change in $\mathrm{pH}$, following the change in titratable acidity (TA) and oxidation; and (3) ethylene production (Figure 1C).

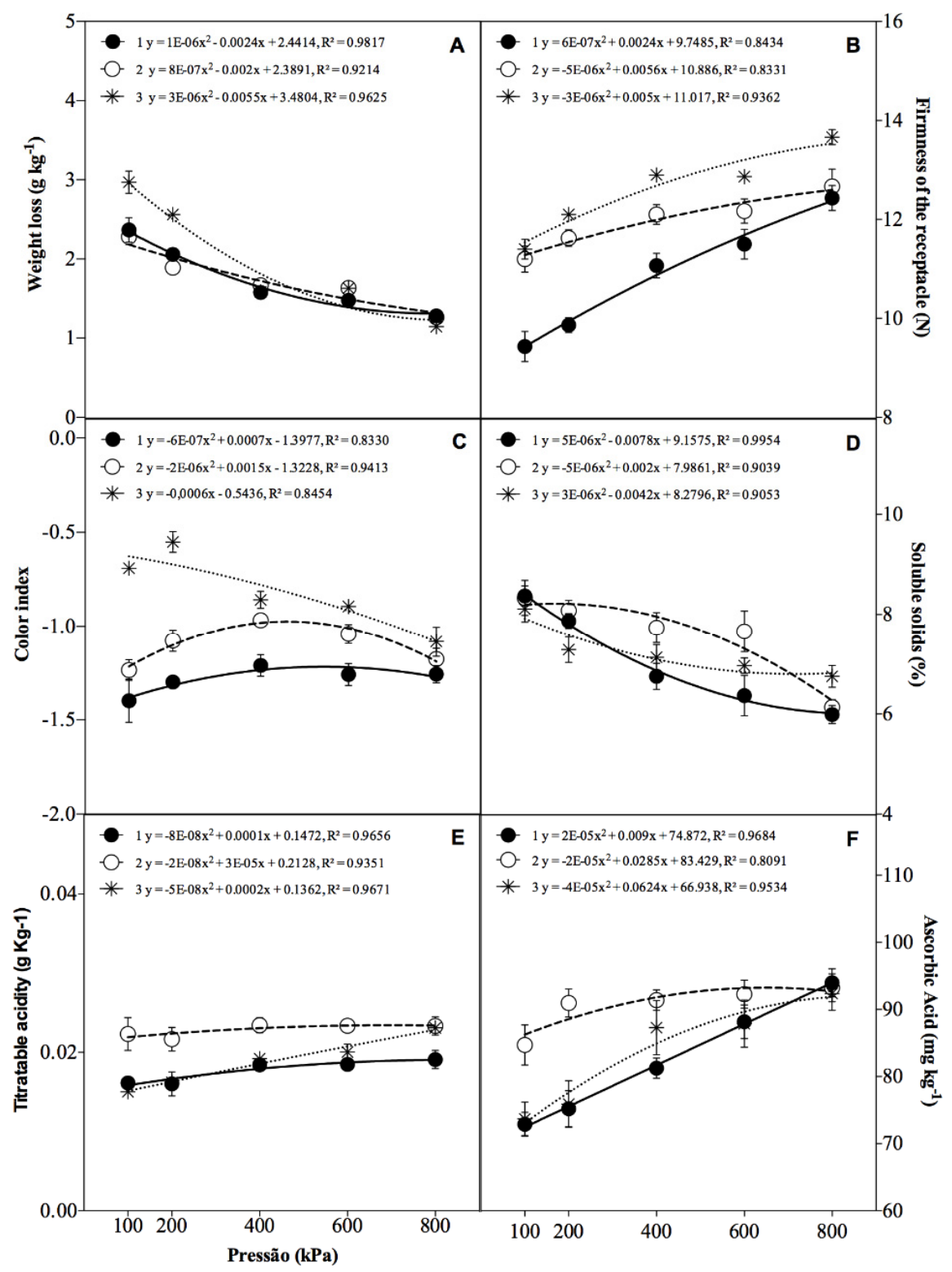

Figure 1. Weight loss (A), firmness (B), color index (C), soluble solids (D), titratable acidity (E), and ascorbic acid (F) in broccoli 'Legacy' submitted to hyperbaric treatments during 1, 2, and 3 days at $22{ }^{\circ} \mathrm{C}$ and $95 \% \mathrm{RH}$. Color index: $0=$ yellow; $-2.0=$ green. The error bar identifies the standard deviation of $5 \%$ of the mean.

The SS content decreased with increasing pressures, with the mean of the control being $20 \%$ higher than the inflorescences submitted to $800 \mathrm{kPa}$ pressure (Figure 1D). The SS reduction was also observed in tomatoes subjected to $800 \mathrm{kPa}$ pressure for six days [6]. On the other hand, the SS content in 'Italy' broccoli stored in different types of packages increases during the storage period [21]. Thus, the application of pressure probably improved the conservation of the vegetables, indicating a delay in senescence.

The TA contents ranged from 0.14 to $0.26 \mathrm{~g} \mathrm{~kg}^{-1}$ (Figure 1E). The hyperbaric pressure improved organic acids preservation in broccoli compared to control inflorescences. The pressure of $800 \mathrm{kPa}$ at three days of storage provided the highest levels of TA. The effect 
of hyperbaric atmospheres on the increase in TA also occurs in fruits, as in mangoes, for example [22].

TA values of plants also depend on genetic, agronomic, climatic, and postharvest factors. For example, broccoli 'Italia' has higher TA values than those found in this study, reaching 0.53 to $0.77 \mathrm{~g} \mathrm{~kg}^{-1}$ of pulp [21]. This divergence may be attributed to cropping conditions [23].

The AA content of control broccoli was reduced by $27 \%$ compared to the initial value (99.6 $\mathrm{mg} \mathrm{kg}^{-1}$, Figure 1F, Table 1). The $800 \mathrm{kPa}$ treatment maintained the highest AA levels $\left(94 \mathrm{mg} \mathrm{kg}^{-1}\right.$ ) regardless of the pressure time.

\subsection{Physiological Phenomena}

Production of Ethylene and Respiratory Rate

The increase in atmospheric pressure around broccoli effectively reduced the respiratory rate of broccoli 'Legacy' (Figure 2A). Broccoli submitted to hyperbaric pressures

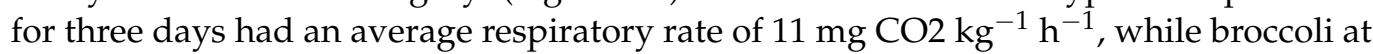
$100 \mathrm{kPa}$ presented respiratory rates of $13.5 \mathrm{mg} \mathrm{CO}^{2} \mathrm{~kg}^{-1} \mathrm{~h}^{-1}$ (Figure 3).
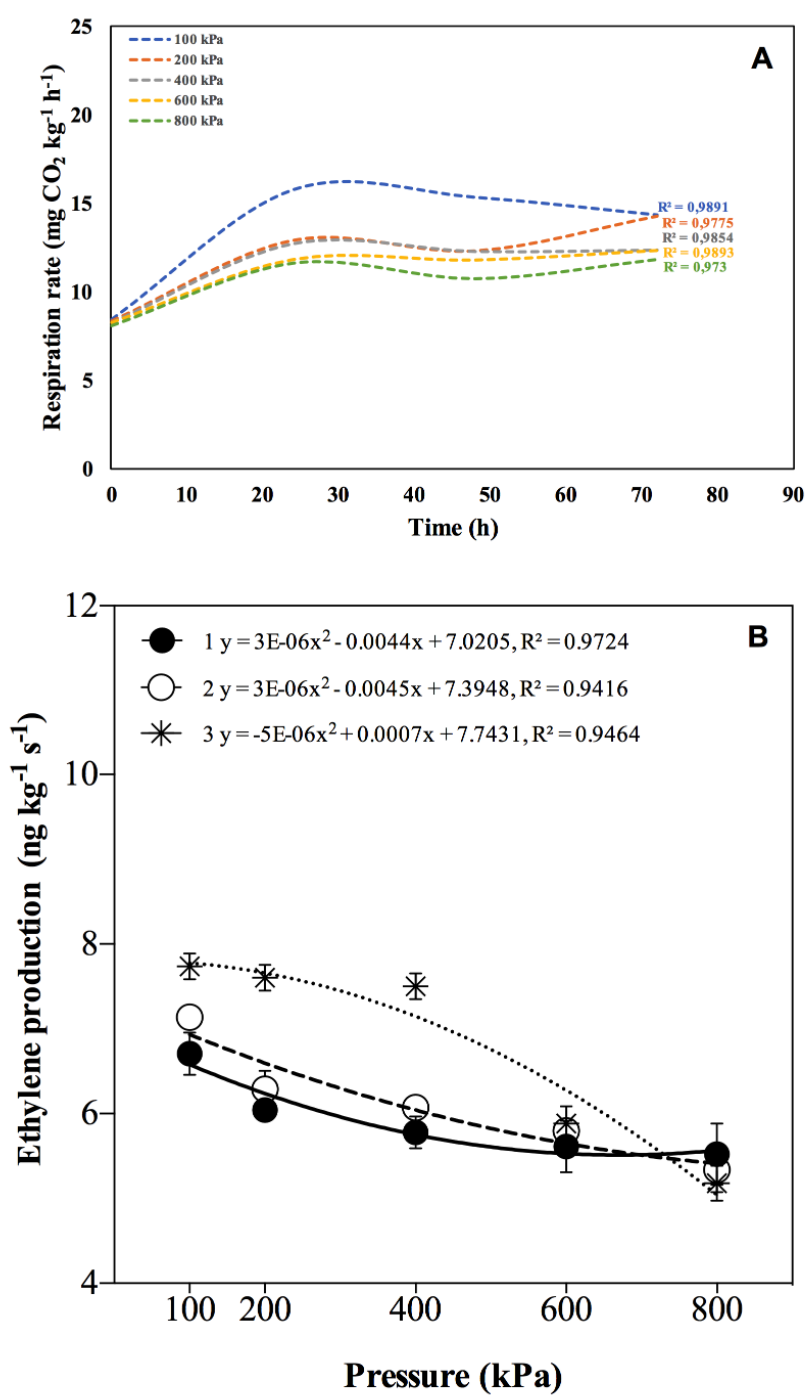

Figure 2. Relationship between respiration rate (A) and ethylene production (B) in broccoli 'Legacy' with pressures applied at times 1,2 , and 3 days at $22{ }^{\circ} \mathrm{C}$ and $95 \% \mathrm{RH}$. The error bar identifies the standard deviation of $5 \%$ of the mean. 


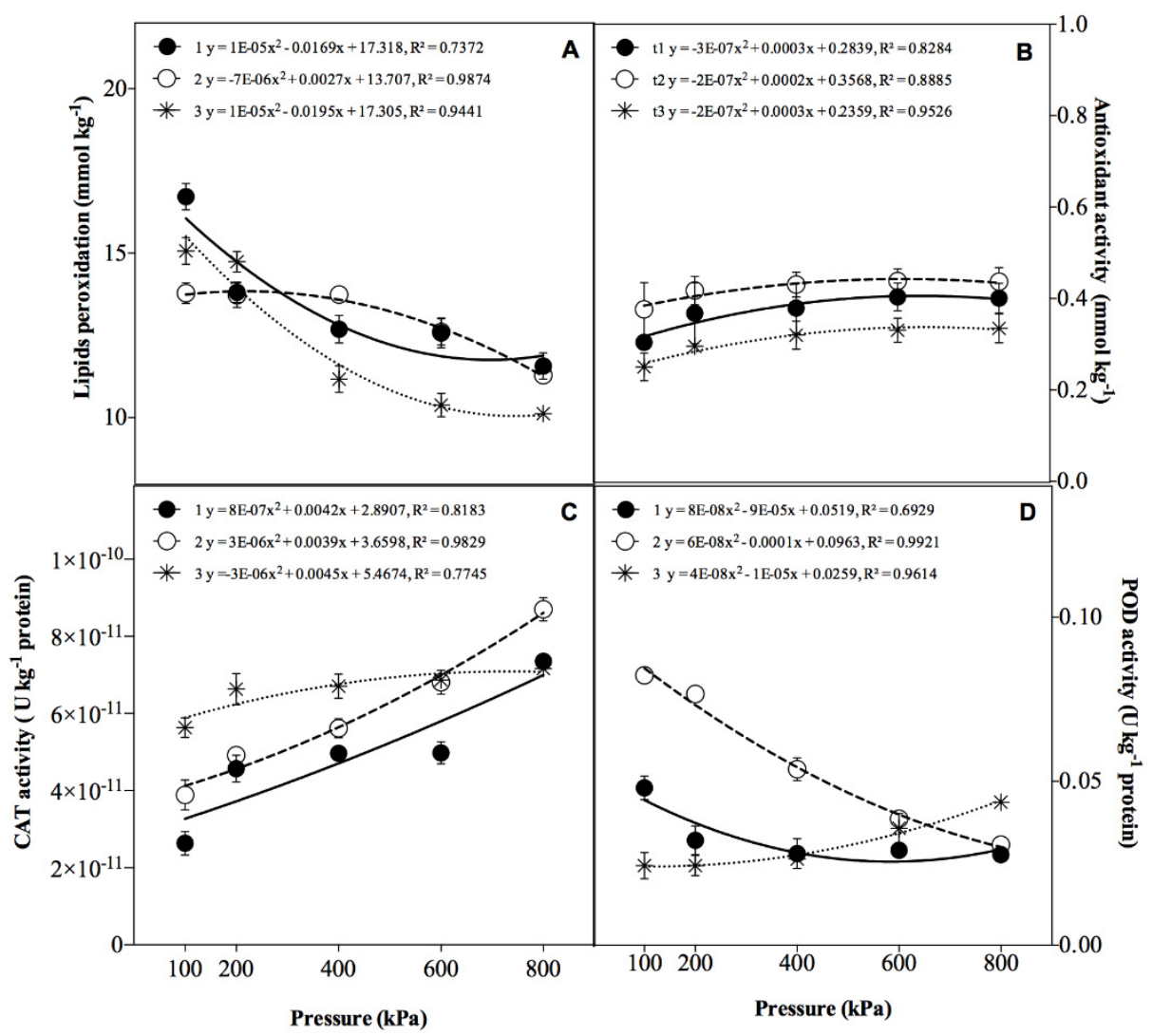

Figure 3. Lipid peroxidation (A), antioxidant activity (B), catalase activity (C), peroxidase activity (D) in broccoli 'Legacy' submitted to hyperbaric treatments during 1, 2, and 3 days at $22{ }^{\circ} \mathrm{C}$ and $95 \%$ $\mathrm{RH}$. The error bar identifies the standard deviation of $5 \%$ of the mean.

The production of ethylene in broccoli increased as a function of time of exposure to pressures, showing a quadratic relation. Increased pressure maintained ethylene production at low levels (Figure 2B). Broccoli submitted to pressures of 600 and $800 \mathrm{kPa}$ for one day presented ethylene production about $16 \%$ lower than the control and very close to the initial values $\left(5.2 \mathrm{mg} \mathrm{kg}^{-1} \mathrm{~s}^{-1}\right)$. After three days, control broccoli produced even more ethylene, and the difference for the best treatment ( $800 \mathrm{kPa}$ ) increased to $33.6 \%$ (Figure 1C).

\subsection{Biochemical Analyses}

Lipid Peroxidation, Total Antioxidant Activity (TAA), Activity of the CAT, and Activity of the POD

The maintenance of the AA contents under high pressures agrees with the increase in lipid peroxidation (Figure 3A), since the control presented the highest values of MDA regardless of the pressure period, with an average increment of $28 \%$ compared to the pressure of $800 \mathrm{kPa}\left(12.5 \mathrm{mmol} \mathrm{kg}^{-1}\right)$.

The content of TAA increased with the applied pressure, regardless of the period of exposure (Figure 3B). TAA values ranged from 0.30 to $0.38 \mu \mathrm{mol} \mathrm{TEAC} 100 \mathrm{~g}^{-1} \mathrm{FW}$ on one day of exposure to pressure, 0.37 to 0.43 on two days, and from 0.25 to 0.32 on three days (Figure 3B).

The hyperbaric pressure significantly influenced the activity of the CAT and POD enzymes of broccoli $(p<0.01$; Figure 3C,D). 


\section{Discussion}

\subsection{Physicochemical Analyses}

Weight Loss, Firmness, Color Index (CI), Soluble Solids (SS), Titratable Acidity (TA), Ascorbic Acid Content (AA)

The alteration of atmospheric pressure is a leading factor influencing the vapor pressure in the environment [6]. The difference between the vapor pressure of water in intercellular spaces of plant tissue and the surrounding air controls the rate of water loss in fresh vegetables. Thus, decreasing the difference in vapor pressure between vegetable and ambient air reduces water loss from plant tissue [24]. Such a process explains the higher mass losses in the broccoli under control treatment $(100 \mathrm{kPa})$. This effect also occurs in other fruits and vegetables when submitted to high pressures $[6,9,25,26]$.

The maintenance of firmness in fruits and vegetables depends on factors such as tissue turgor and cell wall degradation [27], which influence the weight loss in vegetables. Our data suggest that the difference in the firmness of broccoli relates to the weight loss because the broccoli with greater firmness presented a smaller loss of mass (Figure 1A). This correlation also occurs in several other vegetables, for example, the 'Debora' tomato [6] and lettuces [26].

Broccoli with firmness around $13.8 \mathrm{~N}$ are suitable for commercialization, as they maintain the visual characteristic of turgidity [21]. Thus, we can conclude that the broccoli stored under the pressures of 400,600 , and $800 \mathrm{kPa}$ presented adequate firmness for commercialization until the third day of storage at $22^{\circ} \mathrm{C}$ (Figure 1B).

The pressures of 400,600, and $800 \mathrm{kPa}$ preserved the green color of inflorescences, showing a lower color index than the inflorescences submitted to the pressures of 100 and $200 \mathrm{kPa}$ (Figure 1C). The relationship between CI and TA was inversely proportional to third day of pressure, that is, as CI decreased, TA increased (Figure 1C,E). This correlation can be attributed to chlorophyll degradation due to enzymatic activity, causing the yellowing of inflorescences and the release of organic acids in the cellular environment, which increases the TA values.

The highest values of ethylene production and SS content occurred in the control inflorescences, indicating their advanced senescence when compared to the broccoli submitted to $800 \mathrm{kPa}$ (Figure 1D). The increase of SS in control broccoli can be attributed to the high activity of enzymes involved in cell wall degradation [28] with consequent reduction of firmness (Figure 1B) and increased respiratory rate (Figure 2A).

Reduction of acidity during postharvest relates to ripening or senescence due to increased consumption of organic acids in the respiratory process or conversion of acids to sugars in glycogenesis. In the control broccoli, in addition to lower acidity (Figure 1E), they had a higher respiratory rate (Figure 2A), higher ethylene production (Figure 2B), and higher soluble solids (SS) content (Figure 1D), suggesting a greater metabolic activity than the other treatments.

Ascorbic acid content tends to decrease with maturation and storage time [29]. Possibly, the AA was consumed in metabolic reactions in the senescence process of control broccoli, whereas high-pressure application precluded such metabolic reactions (Figure 1E).

Tomatoes submitted to high pressures also present higher AA values when compared to fruits under control pressure [9].

Ascorbic acid is an antioxidant compound that plays a vital role in free radical suppression [30,31], with the ability to donate electrons to a wide range of enzymatic and non-enzymatic reactions [32]. The metabolism of AA acts on the defense to oxidative stress [33], that is, the higher the stress occurring in the vegetable, the lower the concentration of this compound. In this case, the stress was generated by the natural senescence of broccoli, which triggered reactions of degradation and oxidation, reducing postharvest life. The high pressures exerted on the vegetable acted in the metabolism as a whole, slowing the senescence and keeping the levels of AA elevated. 


\subsection{Physiological Phenomena}

Production of Ethylene and Respiratory Rate

The increase in atmospheric pressure around broccoli effectively reduced the respiratory rate of broccoli 'Legacy'. Broccoli submitted to hyperbaric pressures for three days had an average respiratory rate of $11 \mathrm{mg} \mathrm{CO}_{2} \mathrm{~kg}^{-1} \mathrm{~h}^{-1}$, while broccoli at $100 \mathrm{kPa}$ presented respiratory rates of $13.5 \mathrm{mg} \mathrm{CO}_{2} \mathrm{~kg}^{-1} \mathrm{~h}^{-1}$ (Figure 2A). The broccoli respiratory rate at $800 \mathrm{kPa}$ pressure was $18.5 \%$ lower than the control. The reduction in respiratory rate due to the increase in atmospheric pressure also occurs in several fruits and vegetables, such as the fruits of Prunus mume [34], lettuce [26], and tomatoes [9].

The lower respiratory rates achieved by the treatments with high pressures may be due to the solubilization of $\mathrm{CO}_{2}$ within the broccoli and its posterior dilution in the recipients as a result of the increase in the partial pressures of the air gases inside the hyperbaric chambers [25]. The $\mathrm{CO}_{2}$ generated by the broccoli respiration was probably solubilized in the internal tissues until it reached the partial pressure of the $\mathrm{CO}_{2}$ of the surrounding air. Subsequently, $\mathrm{CO}_{2}$ was diluted inside the hyperbaric chamber, causing an increase in the $\mathrm{CO}_{2}$ partial pressure of the air surrounding the vegetable with the rise in $\mathrm{CO}_{2}$ concentration inside the chamber. This process of dilution and solubilization is continuous and stabilizes only when the amount of $\mathrm{CO}_{2}$ exiting the chamber into the gas analyzer becomes equal to that generated by the respiratory rate of the plants [26]. However, the strength of the effect of hyperbaric pressures on the respiratory rates of plants depends on the type of material studied, exposure time, pressure intensity, and temperature.

Ethylene production should be controlled and kept low because it induces chlorophyll degradation with consequent yellowing of broccoli [35]. This effect was observed in the control inflorescences when compared to those submitted to $800 \mathrm{kPa}$, with the lowest ethylene production (Figure 2B) and the highest color index (Figure 1C), impairing appearance and decreasing shelf life [34,36].

Regardless of the pressure time, the ethylene values observed in broccoli subjected to pressures of 600 and $800 \mathrm{kPa}$ were similar, indicating that the range between $600-800 \mathrm{kPa}$ can be used to control ethylene biosynthesis in broccoli.

The inhibition of ACC oxidase (1-aminocyclopropane-1-carboxylate) activity, the enzyme responsible for converting ACC into ethylene, caused by the high pressure, may have kept low ethylene production. Prunus mume fruits submitted to $5 \mathrm{MPa}$ pressure showed a $75 \%$ reduction in ACC oxidase activity compared to the control (100 kPa), while substrate levels (ACC) remained unchanged [37].

\subsection{Biochemical Analyses}

Lipid Peroxidation, Total Antioxidant Activity (TAA), Activity of the CAT and Activity of the POD

Oxidative stress comprises a central factor in biotic and abiotic stress phenomena, occurring during an imbalance between the reactive oxygen species (ROS) production and antioxidant defense in any compartment of a plant cell [38]. Oxidative stress can be measured by lipid peroxidation, which begins with the reaction of a free radical and unsaturated fatty acid, propagating by peroxyl radicals, and resulting in the lipid hydroperoxides and aldehydes formation, such as malondialdehyde, 4-hydroxynonenal, and isoprostanes [39]. This process may occur in all living organisms and can trigger lesions in cells [30], altering membranes and leading to permeability disorders and cell death.

The lower levels of MDA in broccoli submitted to high pressures indicate the efficiency of this treatment in oxidative stress reduction. However, the influence of hyperbaric pressures on MDA is still unclear, with scarce reports in the literature. The three-day pressure treatment showed the lowest MDA values (Figure 3A). The MDA reduction was also observed in tomatoes preserved under high pressure $[9,40]$.

The increase in TAA content as a function of pressure was also observed in 'Debora' tomatoes [9] and in mangoes [22]. This behavior may be attributed to a hormesis effect promoted by increased hyperbaric pressure. 
Broccoli that remained at $800 \mathrm{kPa}$ for 1 and 2 days had CAT activity 2.5 times higher than control broccoli (Figure 3C). CAT plays a crucial role in maintaining hydrogen peroxide homeostasis in plant cells. The enzyme disproportionates the $\mathrm{H}_{2} \mathrm{O}_{2}$ generated in peroxisomes by oxidases involved in $\beta$-oxidation of fatty acids, photorespiration, and purine catabolism $[30,41]$. Therefore, maintaining high CAT activity is a defense mechanism against stress factors [42]. In this sense, the hyperbaric treatments were efficient due to the storage under high pressure activating the $\mathrm{CAT}$, which is directly related to the process of detoxification of $\mathrm{H}_{2} \mathrm{O}_{2}$ and indirectly to the protection of cells.

After two days of treatment, the control broccoli presented the POD activity 2.7 times higher than broccoli submitted to $800 \mathrm{kPa}$ (Figure 3D). However, inflorescences treated with three days of pressure showed opposite behavior, since the highest values of POD activity were observed in inflorescences treated with $800 \mathrm{kPa}$ (Figure 3D).

The higher pressures increased CAT activity and reduced POD activity (Figure 3C,D). Since the main function of CAT in plant metabolism is to rapidly convert hydrogen peroxide (toxic) into other compounds less harmful to the plant, and peroxide is the main substrate of POD, it was expected that the lower availability of peroxide in the intracellular medium would hinder POD activity.

The senescence may have induced the high POD levels of control inflorescences after two days of storage since high levels of POD are associated with the oxidative deterioration of fruits at an advanced stage of maturity [29]. In this aspect, the pressures of 600 and $800 \mathrm{kPa}$ were efficient in keeping low enzymatic activity and propitiating the better conservation of the broccoli when compared to the control inflorescences (Figure 3D).

\section{Conclusions}

The hyperbaric treatments exerted efficient conservation on the postharvest of broccoli 'Legacy', mainly in the highest pressures. The pressures of 400, 600, and $800 \mathrm{kPa}$ reduced the respiratory rate of the vegetables and the production of ethylene and maintained the fresh weight, firmness, and green color, which are essential characteristics for commercialization. The pressures of 600 and $800 \mathrm{kPa}$ influenced antioxidant activity, leading to a reduction in lipid peroxidation and peroxidase enzyme, which preserved tissue integrity and delayed the senescence of broccoli.

Author Contributions: This study was conducted by E.M.P., who was responsible for conducting the study; carrying out the analyses; tabulating the data; and assembling the texts, figures, and tables. J.S.P.J., A.S.F., M.T.C., K.T.E.F.O. and I.N.F.C. assisted with experiment set-up, execution of the analyses, and the literature review necessary for writing this article. B.-H.M. was responsible for providing the resources for carrying out the experiment, including the necessary equipment and reagents. All authors have read and agreed to the published version of the manuscript.

Funding: This research was funded by Coordination of Improvement of Higher Education PersonnelBrazil (CAPES) - Financing Code 001 and the São Paulo Research Foundation (FAPESP) for financial support (Case No. 2017/17024-0).

Acknowledgments: We thank the support of the Coordination of Improvement of Higher Education Personnel_Brazil (CAPES)—Financing Code 001 and the São Paulo Research Foundation (FAPESP) for financial support (Case No. 2017/17024-0).

Conflicts of Interest: The authors declare no conflict of interest. The funders had no role in the design of the study; in the collection, analyses, or interpretation of data; in the writing of the manuscript; or in the decision to publish the results.

\section{References}

1. FAO (Food and Agriculture Organization of the United Nations). Faostat Database Results. 2018. Available online: http: //www.fao.org/home/en/ (accessed on 28 October 2019).

2. Kristal, A.R.; Lampe, J.W. Brassica Vegetables and Prostate Cancer Risk: A Review of the Epidemiological Evidence. Nutr. Cancer 2002, 42, 1-9. [CrossRef] [PubMed]

3. De Carvalho, P.G.B.; Machado, C.M.M.; Moretti, C.L.; Fonseca, M.E.D.N. Hortaliças como alimentos funcionais. Hortic. Bras. 2006, 24, 397-404. [CrossRef] 
4. Ning, X.; Lee, J.; Han, C. Drying characteristics and quality of red ginseng using far-infrared rays. J. Ginseng Res. 2015, 39, 371-375. [CrossRef]

5. Gioppo, M. Postharvest of Cotton, Red Cabbage and Surface in Different Environments and Regulators. Master's Thesis, UEPG, Ponta Grossa, Brazil, 2011.

6. Inestroza-Lizardo, C.; Mattiuz, B.H.; da Silva, J.P.; Galati, V.C.; Voigt, V. Hyperbaric pressure at room temperature increases post-harvest preservation of the tomato cultivar 'Débora'. Sci. Hortic. 2018, 228, 103-112. [CrossRef]

7. Liplap, P.; Vigneault, C.; Toivonen, P.; Charles, M.T.; Raghavan, G.V. Effect of hyperbaric pressure and temperature on respiration rates and quality attributes of tomato. Postharvest Biol. Technol. 2013, 86, 240-248. [CrossRef]

8. Vigneault, C.; Leblanc, D.I.; Goyette, B.; Jenni, S. Invited review: Engineering aspects of physical treatments to increase fruit and vegetable phytochemical content. Can. J. Plant. Sci. 2012, 92, 373-397. [CrossRef]

9. Inestroza-Lizardo, C.; Mattiuz, B.-H.; da Silva, J.P.; Voigt, V.; Muniz, A.C.; Pinsetta, J.S. Effect of hyperbaric pressure on the activity of antioxidant enzymes and bioactive compounds of cv. 'Débora' tomatoes. Sci. Hortic. 2019, 249, 340-346. [CrossRef]

10. Baba, T.; Ikeda, F. Use of high pressure treatment to prolong the postharvest life of mume fruit (Prunus mume). Acta Hortic. 2003, 373-377. [CrossRef]

11. Goyette, B. Hyperbaric Treatment to Enhance Quality Attributes of Fresh Horticultural Produce. Ph.D. Thesis, Department of Bioresource Engineering, McGill University, Montreal, QC, Canada, 2010.

12. Paula, J.T. Postharvest Conservation Methods of Cashew Stalk. Ph.D. Thesis, University of Sao Paulo, Sao Paulo, Brazil, 2017.

13. Goyette, B.; Vigneault, C.; Wang, N.; Raghavan, V. Conceptualization, design and evaluation of a hyperbaric respirometer. J. Food Eng. 2011, 105, 283-288. [CrossRef]

14. AOAC. Official Methods of Analysis of the Association of Official Analytical Chemists International, 16th ed.; Cunniff, P., Ed.; AOAC: Washington, DC, USA, 1997; Chaper 37; p. 2.

15. Heath, R.L.; Packer, L. Photoperoxidation in isolated chloroplasts: I. Kinetics and stoichiometry of fatty acid peroxidation. Arch. Biochem. Biophys. 1968, 125, 189-198. [CrossRef]

16. Brand-Williams, W.; Cuvelier, M.; Berset, C. Use of a free radical method to evaluate antioxidant activity. LWT-Food Sci. Technol. 1995, 28, 25-30. [CrossRef]

17. Kar, M.; Mishra, D. Catalase, Peroxidase and Polyphenoloxidase Activities during Rice Leaf Senescence. Plant. Physiol. 1976, 57, 315-319. [CrossRef]

18. Lima, G.P.P.; Brasil, O.G.; De Oliveira, A.M. Poliaminas e atividade da peroxidase em feijão (Phaseolus vulgaris L.) cultivado sob estresse salino. Sci. Agricola 1999, 56, 21-26. [CrossRef]

19. Bradford, M.M. A rapid and sensitive method for the quantitation of microgram quantities of protein utilizing the principle of protein-dye binding. Anal. Biochem. 1976, 72, 248-254. [CrossRef]

20. Kader, A.A. Postharvest biology and technology: An Overview. In Postharvest Technology of Horticultural Crops; Kader, A.A., Ed.; University of California Agriculture and Natural Resources: Davis, CA, USA, 2002.

21. Barbosa, J.C.; Maldonado, W., Jr. AgroEstat-Sistema para Análises Estatísticas de Ensaios Agronômicos; Version 1.1. 0.711; Jaboticabal: São Paulo, Brazil, 2014.

22. Silva, J.P.D. Effect of Hyperbaric Atmospheres on Postharvest of Mango Palmer. Ph.D. Thesis, Universidade Estadual Paulista Júlio de Mesquita Filho, Sao Paulo, Brazil, 2016.

23. Beckles, D. Factors affecting the postharvest soluble solids and sugar content of tomato (Solanum lycopersicum L.) fruit. Postharvest Biol. Technol. 2012, 63, 129-140. [CrossRef]

24. Padula, M.L.; Carciofi, B.A.M.; Dannenhauer, C.E.; Stringari, G.B.; Monteiro, A.R. Influence of different types of packaging on the physicochemical characteristics and gaseous composition of minimally processed organic Broccoli (Brassica oleracea L. var Itálica) and stored under refrigeration. Braz. J. Food Nutr. 2009, 17, 259-268.

25. Goyette, B.; Charles, M.T.; Vigneault, C.; Raghavan, V. Effect of Hyperbaric Treatment on Quality Attributes of Tomato Fruits. J. Plant Sci. 2010, 1, 541-551. [CrossRef]

26. Liplap, P.; Boutin, J.; Leblanc, D.I.; Vigneault, C.; Raghavan, G.S.V. Effect of hyperbaric pressure and temperature on respiration rates and quality attributes of Boston lettuce. Int. J. Food Sci. Technol. 2013, 49, 137-145. [CrossRef]

27. Fagundes, C.; Moraes, K.; Pérez-Gago, M.; Palou, L.; Maraschin, M.; Monteiro, A. Effect of active modified atmosphere and cold storage on the postharvest quality of cherry tomatoes. Postharvest Biol. Technol. 2015, 109, 73-81. [CrossRef]

28. Maftoonazad, N.; Ramaswamy, H.S.; Marcotte, M. Shelf-life extension of peaches through sodium alginate and methyl cellulose edible coatings. Int. J. Food Sci. Technol. 2008, 43, 951-957. [CrossRef]

29. Chitarra, M.I.F.; Chitarra, A.B. Pós-Colheita de Frutas e Hortaliças: Fisiologia e Manuseio, 2nd ed.; UFLA: Lavras, Brazil, 2005.

30. Gill, S.; Tuteja, N. Reactive oxygen species and antioxidant machinery in abiotic stress tolerance in crop plants. Plant. Physiol. Biochem. 2010, 48, 909-930. [CrossRef] [PubMed]

31. Kaur, C.; Walia, S.; Nagal, S.; Walia, S.; Singh, J.; Singh, B.B.; Saha, S.; Singh, B.; Kalia, P.; Jaggi, S.; et al. Functional quality and antioxidant composition of selected tomato (Solanum lycopersicon L.) cultivars grown in Northern India. LWT Food Sci. Technol. 2013, 50, 139-145. [CrossRef]

32. Das, K.; Roychoudhury, A. Reactive oxygen species (ROS) and response of antioxidants as ROS-scavengers during environmental stress in plants. Front. Environ. Sci. 2014, 2. [CrossRef] 
33. Tsaniklidis, G.; Delis, C.; Nikoloudakis, N.; Katinakis, P.; Aivalakis, G. Low temperature storage affects the ascorbic acid metabolism of cherry tomato fruits. Plant. Physiol. Biochem. 2014, 84, 149-157. [CrossRef]

34. Jones, R.B.; Faragher, J.D.; Winkler, S. A review of the influence of postharvest treatments on quality and glucosinolate content in broccoli (Brassica oleracea var. italica) heads. Postharvest Biol. Technol. 2006, 41, 1-8. [CrossRef]

35. Yamauchi, N.; Funamoto, Y.; Kanetsune, Y. Involvement of Chlorophyll Degrading Enzymes with Chlorophyll Degradation in Stored Broccoli (Brassica oleracea L.) Florets. Food Sci. Technol. Res. 1999, 5, 300-303. [CrossRef]

36. Moreno-Fernández, D.; Carvajal, M.; López-Berenguer, C.; García-Viguera, C. Chemical and biological characterisation of nutraceutical compounds of broccoli. J. Pharm. Biomed. Anal. 2006, 41, 1508-1522. [CrossRef]

37. Baba, T.; Como, G.; Ohtsubo, T.; Ikeda, F.; Lizada, M. Effects of High-pressure Treatment on Mume Fruit (Prunus mume). J. Am. Soc. Hortic. Sci. 1999, 124, 399-401. [CrossRef]

38. Foyer, C.H.; Noctor, G. Oxygen processing in photosynthesis: Regulation and signalling. New Phytol. 2000, 146, 359-388. [CrossRef]

39. Lima, E.S.; Abdalla, D.S. Lipid peroxidation: Mechanisms and evaluation in biological samples. J. Pharm. Sci. 2001, 37, 293-303.

40. Kou, X.; Wu, J.Y.; Wang, Y.; Chen, Q.; Xue, Z.; Bai, Y.; Zhou, F. Effects of Hypobaric Treatments on the Quality, Bioactive Compounds and Antioxidant Activity of Tomato. J. Food Sci. 2016, 81, H1816-H1824. [CrossRef] [PubMed]

41. Igamberdiev, A.U.; Lea, P.J. The role of peroxisomes in the integration of metabolism and evolutionary diversity of photosynthetic organisms. Phytochemistry 2002, 60, 651-674. [CrossRef]

42. Boonkorn, P. Impact of hot water soaking on antioxidant enzyme activities and some qualities of storage tomato fruits. Int. Food Res. J. 2016, 23, 934-938. 